University of Nebraska - Lincoln

DigitalCommons@University of Nebraska - Lincoln

Papers in the Earth and Atmospheric Sciences

Earth and Atmospheric Sciences, Department

10-1935

\title{
CONSERVATION OF THE PREHISTORIC REMAINS OF NEBRASKA
}

Alvin Leonard Lugn

University of Nebraska-Lincoln

Follow this and additional works at: https://digitalcommons.unl.edu/geosciencefacpub

Part of the Earth Sciences Commons

Lugn, Alvin Leonard, "CONSERVATION OF THE PREHISTORIC REMAINS OF NEBRASKA" (1935). Papers in the Earth and Atmospheric Sciences. 364.

https://digitalcommons.unl.edu/geosciencefacpub/364

This Article is brought to you for free and open access by the Earth and Atmospheric Sciences, Department of at DigitalCommons@University of Nebraska - Lincoln. It has been accepted for inclusion in Papers in the Earth and Atmospheric Sciences by an authorized administrator of DigitalCommons@University of Nebraska - Lincoln. 


\section{CONSERVATION OF THE PREHISTORIC REMAINS OF NEBRASKA}

A RESOLUTION has recently been adopted by both houses of the Nebraska legislature to conserve the scientifically very valuable deposits of fossil and other prehistoric remains which occur in the state. This is not to be construed as an unfriendly move on the part of the sponsors of this act. The Nebraska Geological Survey welcomes serious scientific study and research within the state by all persons and institutions who seriously desire to investigate and collect for purely scientific purposes. There is no intention to restrict or curtail the collection of materials by properly accredited representatives of educational institutions and museums. It is hoped that this act will encourage greater cooperation and more complete understanding between scientists from without the state, who come to Nebraska, and the personnel of the Nebraska Geological Survey, the Nebraska State Museum, and other properly constituted staffs of scientists within the state. Persons or institutions who desire to collect in Nebraska should make contact with the state geologist or an authorized representative of the Nebraska State Geological Survey. No set of specific regulations are at present contemplated and such may not be found necessary, if all persons concerned cooperate to the fullest extent.

It is hoped that this act will discourage and prevent the commercial exploitation of all kinds of prehistoric remains by citizens of the state and other persons from without. Also, it is desirable to prevent the unskilled digging of fossils, et cetera, by untrained persons, and the exploitation of valuable deposits by any one whose motives may not be strictly scientific or whose activity may not result in the greatest possible scientific use of the materials. Amateur local collectors are not to be discouraged in their pursuit of scientific information, but museum directors, to whom collections from Nebraska are offered for sale, are advised to communicate with the state geologist regarding the status of the collector and whether authorization has been issued permitting such disposal of materials. It is hoped that all collectors and parties will fully regard the prior claims that other collectors may have, by right of discovery or by grant by other discoverers, to sites and quarries, which have been opened up in previous seasons. Greater agreement on problems of paleontology and stratigraphy will be possible now than in the past, if all geologists, paleontologists and archeologists working in Nebraska will fully co- operate with the Nebraska State Geological Survey in the spirit of the resolution which is given in full below :

Resolution Regarding the Conservation of Nebraska's Fossil aNd Other Prehistoric Remains

\section{PreAmble}

Resolved:

That WHEREAs, the State of Nebraska has within its borders extensive geologic formations and other deposits containing fossil and other prehistoric remains of great scientific value, and

WHEREAs, the unskilled exploitation of these resources, by untrained workers, has resulted in the destruction of much fine material, and the permanent damage to many of the best deposits,

Therefore, authority is hereby given to the Nebraska State Geological Survey of the Conservation and Survey Division of the University of Nebraska, to regulate and control the collection of such materials within the borders of the State, and to take such steps as may be necessary under its police power, already granted, to conserve these deposits for Nebraska, and to prevent the unscrupulous exploitation of the same by collectors from without the State.

The above resolution was introduced and adopted by the Nebraska House of Representatives on the 14th day of May, 1935, and it was introduced in the Nebraska Senate on May 20 and adopted on May 24, 1935, and has been officially certified by the Chief Clerks of both houses.

$$
\begin{gathered}
\text { A. L. LuGN, } \\
\text { Geologist, Nebraska State Geological } \\
\text { Survey, and Associate Professor of } \\
\text { Geology, University of Nebraska }
\end{gathered}
$$

LINCOLN, NEBRASKA 